\title{
A Vain Fascination: Writing from and about Haiti after the Earthquake
}

\author{
ANDREW LEAK \\ University College London, UK
}

In the wake of the huge earthquake that struck Haiti on 12 January 2010, Haiti instantly became the focus of media attention across the world. At that moment, the tropes that had imprisoned Haiti for two centuries (barbarism, savagery, vodou, the land-that-God-forgot, etc.) began to resurface. Some Haitian intellectuals sought to combat those images, but in so doing they inadvertently revealed their complicity not only in the negative discursive construction of their country, but also in the economic and military re-colonisation of Haiti over the last decade. Adept in the fabrication of replicas of 'post-political' discourse, These Haitian intellectuals are in reality a subset of that country's morally bankrupt political class.

Keywords: Haiti, earthquake, artists, intellectuals, representation, post/coloniality.

\section{Introduction}

Haiti is a country that rarely registers on the consciousness of news media-outside of the USA and Canada at least - unless its president is being deposed or it has been hit by a hurricane. But after a catastrophic earthquake struck Haiti late in the afternoon of 12 January 2010, the world's media cast a spotlight on that country that continued to shine for several weeks, a spotlight that has been re-lit on each of the three subsequent anniversaries - albeit with diminishing intensity. However, that spotlight left some important issues in the shadows. My purpose in this article is to cast a little light into those shadowy recesses. For reasons that I will explain shortly, Haiti was immediately represented in the world's media by a small group of writers who enjoyed some nameprominence in France, Canada and, to a lesser extent, in the USA. Their neutrality or objectivity - not to mention their 'authenticity' - appeared to be guaranteed by the simple labels 'writer' or 'intellectual' or 'educator'. But as I will attempt to show, they had a history. And that history was one of an active, if disavowed, complicity with the reactionary forces - both within their country and outside of it - that have struggled to maintain Haiti's unenviable status as the poorest country in the Western hemisphere.

\section{Reaping What You Sow}

Haiti is the quintessential subaltern: deprived of the right to speak and subject to decisions taken by the elites both inside and outside of the country. Haiti has always 


\section{Writing from and about Haiti after the Earthquake}

been 'known' primarily through the narratives constructed about it in the centres of imperialist power. In finally defeating Napoleon's expeditionary force in 1803, Haiti endowed itself with a symbolic power that far exceeded its actual strength: throughout the nineteenth century, the great dread of the French bourgeoisie-haunted by memories of the Parisian mob during the French Revolution - was the 'haitianisation' of the popular classes, and if Haiti was not recognised by the Land of the Free until 1862, after the secession of the South, it is because of the dangerous example it had set in destroying the institution of slavery. As the Haitian sociologist Jean Casimir has noted, Haiti has always been a country that 'disturbs' (quoted in Dubois, 2012: 11). All forms of economic terrorism, backed up when necessary by means of gunboat diplomacy, were used to subdue this disturbing presence, but the weapon of choice has always been language. Haiti was imprisoned in the trope of barbarism. It was certainly no coincidence that it was during the USA's brutal occupation of Haiti (1915-1934) that lurid novels started to appear portraying Haiti as the Devil's own land, inhabited by cannibals and zombies: these texts were little more than projections of the occupiers' own brutality onto their victims. Many more tropes - by which I mean rhetorical constructs harnessed to an ideological agenda-have followed: despotism, corruption, coups d'état, vodou, poverty, violence. In January 2010, with the dust still not settled on Port-au-Prince, these clichés began to be resurrected by the world's media. In March, the evangelical preacher Pat Robertson assured his listeners on the Christian Broadcasting Network that Haiti owed its freedom to having made a pact with the devil (The Huffington Post, 2010). The likely historical reference in Robertson's claim is to the semi-legendary ceremony at the Bois Caïman in August 1791: presided over by a vodou priest and priestess, it is widely held to have marked the start of the slave revolt (Dubois, 2012: 92). But the idea that Haiti was a cursed land was repeated in newspapers and television studios far more sympathetic to the plight of the Haitians than Robertson and his fundamentalist flock. So pervasive was the idea that Haiti was the object of a presumably divine malediction that it would be tedious to attempt even a cursory enumeration of those articles. The article published by Le Monde on 15 June 2010 under the banner headline 'Haïti, la malédiction' (The Curse on Haiti) and signed by modern historian-cum-reporter Jerôme Gautheret could serve as the epitome. In that article-where, amongst other things, the US occupation is described as an attempt to 'restore a little order [to the country]' - Gautheret pulls off the tour de force of equating two centuries of interventions, exploitation and brutalisation with a succession of natural catastrophes (Gautheret, 2010).

No sooner had these first ill-judged articles appeared than voices were raised in protest. The voices in question were not those of Haiti's accredited representatives - its politicians - but those of Haitian writers and artists. By a curious happenstance, on 12 January 2010 Port-au-Prince was full of Haitian writers. The 'Etonnants Voyageurs' literary festival, organised by Michel Le Bris to promote his notion of 'litterature-monde en français' (world literature in French) was due to open in Port-au-Prince later that week. The organisers had been in place for a week; celebrated novelists such as Dany Laferrière had been doing the rounds of radio and TV stations for days; the poet and publisher Rodney Saint-Eloi (Laferrière's fellow Montréal 'exile') arrived at the Hotel Karibe only an hour or so before the earthquake hit. About twenty more French and francophone writers and academics were scheduled to arrive in the following days. And that is in addition to the many Haiti-based authors - such as Lyonel Trouillot, Yanick Lahens and Gary Victor - who were present and due to participate in the festival. The voices of these writers were amplified in short order by those of a veritable panoply

(c) 2013 The Authors. Bulletin of Latin American Research published by John Wiley \& Sons Ltd on behalf of the Society for Latin American Studies.

Bulletin of Latin American Research Vol. 32, No. 4 
of Haitian intellectuals with connections in the international media. By the autumn of 2010, many of these artists and intellectuals had published books which reproduced and supplemented the articles they wrote and interviews they gave at the time of the earthquake. These are listed at the end of this article.

One of the most urgent tasks for the writers responding to the disaster of 12 January was to combat the discourse being woven around the disaster in the international media. Dany Laferrière, for one, sensed the danger: 'I can see a new label starting to emerge, one that is getting ready to bury us all completely: Haiti is a cursed country. There are even some Haitians who are starting to use it. You have to be really desperate to take on board the contempt of the other for oneself' (Laferrière, 2010: 78). He continued: "All it takes is for one person to launch the word "curse" on the airwaves for it to metastatise like a cancer. Before they start talking about vodou, savagery, cannibalism and vampires, I feel that I still have enough energy to speak out against it' (Laferrière, 2010: 79). I shall return to these cannibals in a moment.

Another cliche doing the rounds concerned the famous 'resilience' of the Haitian people. It fell to another novelist, Yanick Lahens, to inveigh against that particular cliché: 'There is a kind of exoticism in glorifying the resilience of the Haitians. [The foreign press] has turned it into such a leitmotiv that it has become a cliché' (Lahens, 2010b: 142). Lahens's pointed use of the term 'exoticism' signals her awareness that colonial habits die hard. Rodney Saint-Eloi, for his part, wished the word could be struck from the dictionaries (Saint-Éloi, 2010: 259).

Tiring perhaps of vodou, vampires and cannibalism, some French newspapers attempted to present a more upbeat image of Haiti. A week after the seism, Libération invited eight Haitian writers to provide a rectification. One idea runs through these articles: the idea that Haiti's unique artistic vibrancy and creativity was the key to national recovery. Here is Yanick Lahens:

But Haiti provides another quite essential measure of the world - that of creativity. Because we have also forged our resistance to the worst by the constant transformation of pain into human creativity. In what René Char called 'the sanitary virtue of misfortune (la santé du malheur).' I have no doubt that we writers will continue to impart to the world a particular savour. (Lahens, 2010a)

In fairness, Lahens retracted that view in the autumn of 2010, seeing in it a fascinating lure -'I will say, contradicting a very fashionable discourse, that artistic production will not save us. To repeat that it will is to inscribe ourselves within the logic of a vain fascination (une séduction stérile)' (Lahens, 2010b: 156)-although she does appear to have forgotten that she herself had contributed toward making that discourse fashionable in the first place... Her colleague Rodney Saint-Éloi is less circumspect. Here is Saint-Eloi counselling his friend, the polymathic creator Frankétienne: 'Nothing has changed. Don't allow yourself to be intimidated by the earthquake, carry on doing what you know how to do. Culture is the only thing that can put the country back on its feet' (Saint-Éloi, 2010: 83). And again: 'Only art possesses the energy that we need to pick ourselves up again’ (Saint-Éloi, 2010: 83).

It is perhaps always the images that flatter one's own narcissism that are the most difficult to detect and avoid, and that expression, 'une séduction stérile', captures very well the historic tendency of francophone Haitian artists and intellectuals to become fascinated by the gaze of the prestigious Other. As Lahens implies, the result is as devoid of creativity as an image infinitely reflected between two facing mirrors. That need for 


\section{Writing from and about Haiti after the Earthquake}

recognition can attain pathological proportions. Such is the case of the aforementioned Frankétienne, who is obsessed with the idea that he deserves to win the Nobel Prize for Literature (that is to say, to be recognised by the Nobel committee). He told Saint-Éloi that he was glad he had been 'overlooked' for the prize in 2009, since, had he won then, his glory would have been overshadowed by the 450,000 [sic] deaths in the earthquake (Saint-Éloi, 2010: 251).

Not all of the 'Haitian tropes' that resurfaced after the earthquake were manufactured abroad. There is one that echoes through the texts of Laferrière, Lahens and Saint-Eloi and, as far as I can tell, it originated in Haiti. I refer to the 'we are all in it together' refrain. As if anticipating-and attempting to forestall-the press reports of anarchy and looting, writers present on 12 January emphasised the dignity and solidarity of the victims. But Laferrière and Saint-Éloi go much further, detecting in the immediate, human reaction of shell-shocked people the dawning of a new community. As if, in levelling Port-au-Prince, the earthquake had also created a level playing field, sweeping away two centuries of social apartheid. Saint-Éloi remarks:

Rich and poor alike are in this boat that is sinking towards the abyss. They shake hands with each other, afflicted by the same sense of desolation. 'Tout moun jwenn' [everyone gets their share/their slice of the pie] says Jean [the taxi-driver]. Why did it take an earthquake for people to want to make common cause, to have a collective project and to feel this desire to form a crowd and to be fully engaged in their history? Is catastrophe the only thing capable of bringing people together? (Saint-Éloi, 2010: 120)

It is true that the earthquake did not discriminate on social grounds when it struck: if anything, the middle classes were disproportionately affected, as they were the ones most likely to be buried under the concrete of collapsing office blocks and administrative offices. But those 39 seconds of dreadful equality passed in the blink of an eye: the very moment the tremors ceased, the chances of survival were conditioned by money, power and influence. The filmmaker Raoul Peck reports that the instant going rate for digging somebody out of the rubble was $\$ 6000$ - in a country where 80 percent of people live on $\$ 2$ per day (Peck, 2010).

The economics of survival have become even clearer in the three years since the earthquake. Within days, at least 1.5 million people found themselves living in tents or under plastic sheets and scraps of tarpaulin in makeshift camps. More than three years on, 365,000 of them are still there. Predictably, those who were best able to get out of the camps were those with access to funds or to still-habitable property. Those with family in the Haitian diaspora able to send them money did not remain long in the camps. But how does one come to have access to such resources? Who had family in the diaspora? Historically, emigration from Haiti has correlated strongly with level of education. Between 1965 and 2000, 84 percent of Haitians with a tertiary (university level) education left Haiti-compared with just 22 percent in the Dominican Republic (Soukar, 2010: 314). Over the same period, 3 percent of Haitians with only the most basic level of education (primary) emigrated - for the most part to seek work on the Dominican sugar plantations, the bateys. As the Haitian saying has it: 'boujwa-a ap mache avèk viza-l nan pòch li' (lit: the bourgeois walks around with his visa in his pocket, i.e. ready to hand). In turn, access to education is also overwhelmingly predicated on class and wealth: over 90 percent of tertiary educational provision in Haiti is private and fee-paying. For the briefest of moments, then, rich and poor were in the same boat, but today only the poorest of the poor remain in the camps, where

(c) 2013 The Authors. Bulletin of Latin American Research published by John Wiley \& Sons Ltd on behalf of the Society for Latin American Studies. 
they are increasingly subject to illegal evictions, as the International Organisation for Migration - the UN body tasked with protecting the rights of Internally Displaced Persons (IDPs) - looks on.

In unleashing a plethora of writing about Haiti, the earthquake laid bare a certain relation. What interests me in the foregoing discussion is not the discourse about Haiti produced outside Haiti per se, nor the discourse about Haiti produced from within that country, but rather the way those discourses are related, or articulated one on the other. Before moving on to discuss a second level of post-earthquake discourse, I will provide one particularly striking example of this discursive relation. We heard Laferrière vowing to combat the invidious clichés that threatened to 'bury' Haiti before it was too late-before 'they' started to talk about 'vodou, savagery, cannibalism and vampires' (Laferrière, 2010: 79). But within living memory - if not within Laferrière's, apparently - 'they' had been talking at great length about vodou, savagery and cannibalism. Except that in this instance 'they' were not thrill-seeking journos in the foreign press, but Laferrière's own close friends and colleagues, Lyonel Trouillot, Gary Victor and Frankétienne. In a set of interviews published by the journal Africultures shortly after the ouster of Jean-Bertrand Aristide in February 2004, at a moment when Haiti had high visibility in the world's media, these writers were determined to tell the truth about the departed 'despot'. Frankétienne assured the journal's readers that Aristide was guilty of 'plunder, murder, child-sacrifice', that he had 'latched on to the other side of the divinity, the diabolical side' and that 'even Satan has abandoned him, you can see it in his face' (Frankétienne et al., 2004). For his part, Trouillot - apparently hankering after the good old days of Papa Doc, when at least you knew where you were - opined that Aristide was worse than Duvalier because at least the latter 'took responsibility for (assumait) his killings'. Now well into his stride, Trouillot could not resist feeding a last titillating morsel to the interviewer: 'Aristide used vodou as much as Duvalier, or at least a certain kind of vodou [...] A few months ago, a baby disappeared from the general hospital. What a scandal! Of course, everyone knows that Aristide had the child sacrificed in order to win the favour of the loas' (Frankétienne et al., 2004, my emphasis). It apparently did not occur to the interviewer to ask who this 'everybody' was and precisely how they 'knew' these things. Gary Victor dutifully echoes his colleagues: 'Haitian despots have always had recourse to Oungans (vodou priests) or Boko [sic] (sorcerers) to consolidate their power' (Frankétienne et al., 2004). Not a trick was missed: despotism, vodou, savagery, cannibalism. Little wonder that Laferrière was worried. The propagandising of Frankétienne, Trouillot and Victor is to be understood in the context of a much broader campaign of demonisation mounted against Aristide from Autumn 2002 onwards by a so-called civil society group, the G184 (Groupe des 184). All three were enthusiastic members of that group. I shall return to it presently.

Taken in isolation, the Africultures episode is illustrative of a certain mechanism. Information theorists might call it a positive feedback loop ('a' produces ' $b$ ', which produces more of ' $a$ ', which produces more of ' $b$ ' - where ' $a$ ' and 'b' are sites of discursive production inside Haiti and outside of Haiti). Psychoanalysts would more likely be reminded of D.W. Winnicott's description of the basis of narcissistic identification: 'What does the baby see when he or she looks at the mother's face? I am suggesting that, ordinarily, what the baby sees is himself or herself. In other words, the mother is looking at the baby and what she looks like is related to what she sees there' (Winnicott, 1971: 112). Except that, in our case, it is Mother France whose benign approbation is so craved by the francophone Haitian intellectuals. (Not to mention the generous artistic 
subsidies handed out to Haitian writers who take the 'correct' view of Franco-Haitian relations.) Put simply, Haitian intellectuals of the likes of Trouillot and co. feed the images of Haiti produced in the centres of imperialist and neo-colonial power and then react to those images with pathetic gratitude (if they flatter their narcissism) or with uncontrollable fury (should they wound their narcissism). The libellous diatribe unleashed by Trouillot against Peter Hallward in the pages of Small Axe a few years ago is a textbook example of the latter kind of reaction (Trouillot, 2009).

What is said about Haiti is one thing; what is done to it is another. But in very recent history, words have proved to be the prelude to deeds, and Haiti in 2013 is still living with the consequences of those deeds. If the Haitian intelligentsia feign ignorance of their role in the representation of Haiti in Europe and North America, when it comes to their responsibility for the fact that Haiti is now, effectively, an occupied country, their attitude is one of total disavowal. I will develop this assertion with reference to one particularly illuminating work that was written in direct response to the challenges of post-earthquake reconstruction.

\title{
The Disavowal of Responsibility
}

In October 2010 the Quebec publisher Mémoire d'Encrier put out a 400-page volume of essays titled Refonder Haïti? The volume contains 43 pieces written by those who like to think of themselves as Haiti's 'qualitative majority': novelists, historians, sociologists, anthropologists, economists, film-makers, journalists, political scientists. The selection ignores the old inside-outside rivalries between Haitian intellectuals: the contributors are drawn from Canada, France and the USA, as well as from Haiti itself. The editors were Pierre Buteau, Rodney Saint-Eloi and Lyonel Trouillot. The overly modest biographical notes on the editors inform readers that Buteau is an historian and teacher (professeur) at the Université d'Etat d'Haït; Saint-Eloi a writer, publisher (he co-founded Mémoire d'Encrier) and academic; Trouillot a novelist, poet and teacher of literature. In brief, a trio of well-meaning intellectuals and artists, passionately committed to the cause of the Haitian people but apparently standing aloof from the political mêlée. The problematic of the volume is clearly presented in the Introduction:

\begin{abstract}
Re-found what? Should we rebuild on the basis of the devastation that has been left by the earthquake, or re-found on the basis of the past and of history in order to create the anchoring points of renewal, making whatever breaks with the past are necessary in order to construct a fair and just society (une société juste)? (Buteau et al., 2010: 5)
\end{abstract}

The editors of the volume recognise that Haitian society was broken long before the earthquake provided a physical analogue of that dysfunctionality. The task now is to identify the constructive and destructive elements of the past with a view to building a 'common sphere of citizenship (une sphère commune de citoyenneté)'. (Buteau et al., 2010: 5). The range of 'elements' discussed is impressively broad: inequalities in the education system; discrimination against Kreyòl, against women, against children; the undervaluation of popular culture and religion; the need to reform journalistic practices; the need to involve the diaspora in the political life of Haiti; ecological disaster; the importance of good diplomacy [sic!]; the need to eradicate gender-based violence; the need to decentralise, etc. But very few of the contributors appear willing to go directly to the root causes of the situation in which Haiti found itself in the wake of the 
earthquake. One of the best-informed essays in the volume, and one of the few that articulates the reality of Haiti's situation clearly, is 'Construire et reconstruire Haïti? Acteurs, enjeux et représentations [To construct and reconstruct Haïti? Actors, stakes and representations]'. The piece was penned by Émile Brutus and Camille Chalmers. Describing himself as a 'political militant' in his biographical note, Chalmers is a highly educated socio-economist who is the co-ordinator of the Haitian Platform for an Alternative Development (PAPDA), one of Haiti's longest established civil-society organisations. In their article, Chalmers and Brutus develop the unsurprising view that Haiti is the historical 'laboratory' of the neo-liberal project, and provide a succinct summary of Haitian actuality:

A tiny minority, just one percent of the population, owns more than 40 percent of national wealth and puts in place a state system of predation and repression against the majority - the peasants and the urban popular classes - with the support of a proteiform petty bourgeoisie and some imperialist powers. (Brutus and Chalmers, 2010: 35)

Unlike many of the contributors to Refonder Haïti?, Brutus and Chalmers are sceptical about the idea that the earthquake might represent a watershed in Haitian history, let alone a 'tabula rasa'. They point out that the USA and the World Bank had been pursuing the reconfiguration of the Haitian economy for many years prior to the earthquake (when that project was rebaptised as 'reconstruction'), beginning with Reagan's Caribbean Basin Initiative, through the waves of liberalisation of 1983, during the years after the departure of Baby Doc in 1986-1990, throughout the first Préval presidency (1995-2000), right through to Hope 1 and Hope 2 (2007-2008), the latest Poverty Reduction Strategy (2007-2010) and the Collier Plan (2009). In that context, it was obvious that the Post Disaster Needs Assessment of March 2010 would not bring forth any new ideas for the 'reconstruction' of Haiti, let alone its 're-foundation' (Brutus and Chalmers, 2010: 41). Instead of the authors' preferred remedy - democratic, popular socialism - the Haitians have, since 2010, simply seen more of the same: the accelerated development of Free Trade Zones, high-end tourism, the liberalisation of foreign trade (the further lowering of import tariffs), privatisation of the few remaining state-owned enterprises, the further erosion of the prerogatives of the Haitian state and the slashing of the public sector.

So far, so good, but we need to ask ourselves precisely what kind of object we are dealing with in Refonder Haïti?. Chalmers' prescription of 'democratic, popular socialism' strikes a decidedly discordant note in the volume. The introduction, signed by all three editors, strikes a quite different tone. According to them, Haiti does not have 'social classes' but is, rather, made up of 'différentes composantes sociales' (various social constituent parts); and the aim of the volume, they say, is to reflect on how to bring about 'une nouvelle sphère de citoyenneté' (a new sphere of citizenship). Even while they go through the motions of attacking the neo-liberal guardianship of Haiti, the language of most of the contributions is that of the 'post-political' liberal consensus. In couching their analyses and prescriptions in an ethical discourse, vaguely inflected towards human rights, the editors and most of the contributors carefully eschew the properly political - that is to say, the domain of action.

A feeling of uncanniness hangs over the volume, extending to the authors themselves. It is the uncanniness encountered in a dream where a person is simultaneously familiar and unfamiliar: both one person and another. A useful reference here would be Chris Bongie's Friends and Enemies. The Scribal Politics of Post/Colonial Literature, in which 


\section{Writing from and about Haiti after the Earthquake}

he talks (after Debray) of 'the disavowed relation between "mercenary scribes" and their uncanny doubles - the intellectual, the man of letters, and so on' (Bongie, 2008: 33). I referred above to the biographical notes included in Refonder Haïti? as 'over-modest'. Perhaps 'disingenuous' would have been a more accurate description, for two of the editors-Buteau and Trouillot-have political pasts that are somewhat at odds with the personae they create for themselves in the 'notes on contributors'. At this point, we need to go back to ten years before the publication of Refonder Haiti?

After the election of Jean-Bertrand Aristide in 2000, Haiti was plunged into political crisis: the 'opposition' to Aristide's Fanmi Lavalas - who baptised themselves, laughably, the 'Democratic Convergence' - refused to oppose in any recognisable, democratic sense of the term, and chose instead to adopt a 'zero option' designed to bring the country to the point of collapse - at which point, they calculated, the International Community would step in and restore democracy and the rule of law (see, inter alia, Dupuy, 2007; Hallward, 2007; Fleurimond, 2009; Chomsky et al., 2004). In 2002, a 'civil society' front dedicated to the same ends was formed. It was called the Groupe des 184 (G184). It was created by two of Haiti's sweatshop oligarchs: Andy Apaid Jnr. and his brother-in-law, Charles Henri Baker. They succeeded in co-opting a range of civil society organisations (student groups, trades unions, peasant groups, women's groups, church groups), many of which did not actually exist, except in the form of an acronym. The active connections in the G184 had as much to do with clan as with political platforms. The Haitian elites believe in keeping things in the family: Yanick Lahens, a writer whose work I have referred to here, was co-president of the G184 with Apaid; she is the wife of Philippe Lahens (Vice Governor of the Banque Républicaine d'Haiti and former President of the Haitian Chamber of Commerce) and the daughter of a former minister of François Duvalier; her brother Alain Jean Pierre is Secretary General of the Haitian Olympic Committee, whose president is Jean-Edouard Baker. And so on. If the moving force behind the group were the business elites, it was the 'intellectuals' who provided them with their fig-leaf. Indeed, the only named individuals in the G184's membership list are the eighteen members of the 'Cultural Sector (Intellectuals, Writers and Artists)'. In 2003, an offshoot of the G184 called the Collectif Non! was formed by G184 members Lyonel Trouillot, Magalie Comeau-Denis and Syto Cavé.

To return to Refonder Haïti?, no fewer than sixteen of the contributors to that volume were members of the G184 or the Collectif Non!. Trouillot and Buteau were members of both. Between September 2003 and the ouster of Aristide in February 2004, the Collectif Non! put out nine increasingly hysterical press releases which were widely reproduced and treated as fact, especially in the French, US and Canadian media. These press releases contained a mish-mash of half-truths, hyperbole, deliberate obfuscation and, occasionally, outright falsehoods. Their content had the tedious predictability of 'a message from our sponsors'; the same key messages and buzzwords are repeated ad nauseam: Aristide was a despot, a tyrant, a dictator, a drugs trafficker; he had hordes of heavily armed thugs carrying out massacres all over the country etc. When the word 'massacre' did not have the desired effect, the authors escalated it to 'genocide' (Collectif Non!, 2004). Under the pen of Trouillot and co., the huge mass of poor Haitians who had elected Aristide in 2000 found themselves transformed into 'Lavalas henchmen'. That recent history merits barely a mention in the pages of Refonder Haiti?, which is odd given that ' $[t]$ he secret of the future, of any future, resides in the past', as the three editors so sagely remind us (Buteau et al., 2010: 6).

The authors of the Collectif Non! press releases were careful not to call explicitly for intervention by the 'international community' to rid them of that troublesome (former)

(c) 2013 The Authors. Bulletin of Latin American Research published by John Wiley \& Sons Ltd on behalf of the Society for Latin American Studies. 
priest, but that appeal is crystal clear in texts such as that of 31 January 2004, titled 'Jusqu'où ira l'International dans l'acception de l'inacceptable? (Just how far will the International [sic] go in its acceptance of the unacceptable?) (Collectif Non!, 2004). And 'intervention' is precisely what happened on 29 February 2004, when the combination of a tiny paramilitary force and American, Canadian and French special forces effected the removal of Aristide and his banishment into an exile that would last seven years.

The de facto regime imposed by the State Department immediately set about 'stabilising' the country. As documented by numerous international human rights observers, that 'stabilisation' took the form of two years of arbitrary arrests and imprisonment; the return of beatings, torture, 'disappearances' and unexplained deaths in custody; the use of rape as a weapon of war; deadly raids into the shanty towns of Portau-Prince (Griffin, 2004; Amnesty International, 2005; Mance et al., 2006) and blanket impunity - the most egregious example being the night-time court hearing that acquitted Jodel Chamblain and Jackson Jonais, former FRAPH death-squad members previously convicted for their part in the Raboteau massacre of 1994. Amnesty International called the acquittal a 'mockery' and 'an insult to justice' (Amnesty International, 2004).

In the period February 2004-January 2006, it is estimated that some four thousand almost exclusively poor, shanty-dwelling Haitians lost their lives (Hallward, 2007: 277-310). If the actions of Trouillot and the G184 intellectuals contributed directly to bringing about that state of affairs, they had a further consequence that is still shaping the political and economic landscape of Haiti to this day. On 1 June 2004, the Multinational Interim Force (essentially the remnants of the forces that had ousted Aristide) was replaced by a large contingent of United Nations troops (MINUSTAH, or United Nations Mission for the Stabilisation of Haiti) deployed under Statute VII of the United Nations charter. That statute was specifically designed to deal with states whose aggression posed a real and present threat to neighbouring states. Despite its dubious legal justification, the mandate of MINUSTAH has been renewed annually for the last nine years. The terms of its deployment allowed for a much more pro-active engagement than we have seen in real conflict zones such as Rwanda or the Democratic Republic of Congo, and MINUSTAH commanders fulfilled their brief enthusiastically. MINUSTAH forces regularly accompanied Haitian National Police and sundry rightwing paramilitary groups on punitive raids into the poorest quarters of Port-au-Prince. The 6 July 2005 raid on the huge seaside slum Cite Soleil - perceived as a stronghold of Aristide's Fanmi Lavalas party, that is, home to the poorest of the poor who had voted for Aristide en masse in 1990 and 2000 - was one of the most murderous (Hallward, 2007: 286-295).

The stated goal of the UN mission - to restore the rule of law and establish the stability necessary for the democratic process to take its course-was clearly a sham. The troops were deployed as proxy enforcers of US regional policy. Their mission was to destroy the remnants of the popular movement that had first brought Aristide to power in 1990, and to promote the interests of the 'business-friendly' Haitian transnational bourgeoisie. In brief, to further the neo-liberal economic agenda that had subtended US foreign policy in the Caribbean and Latin America ever since it first strove to establish a 'stable business environment' in Brazil, Chile, Argentina and Uruguay in the 1960s and 1970s. This is not speculation on my part: we have it from the horse's mouth. In 2011, Haït Liberté and The Nation published leaked diplomatic cables between Washington and the US Embassy in Port-au-Prince that had been obtained by Wikileaks. In those cables, the then US ambassador Janet Sanderson, noted that ' $[\mathrm{t}]$ he UN Stabilization Mission in Haiti is an indispensable tool in realizing the core USG [US Government] 


\section{Writing from and about Haiti after the Earthquake}

policy interests in Haiti' - interests which included suppressing 'resurgent populist and anti-market economy political forces'. She continues, in a self-congratulatory tone, to boast that MINUSTAH was 'a financial and regional security bargain for the USG' (Ives and Herz, 2011).

One might charitably assume that Trouillot and his G184 colleagues were simply victims of their own naivety, caught up in a cruel game of unintended consequences. If that were the case, Trouillot, Frankétienne, Lahens and Victor would have been horrified by the well-documented human rights abuses that followed the ouster of Aristide; and contrite, perhaps, at having opened the door and invited in an army of occupation. After all, they positioned themselves in their Collectif Non! press releases as politically disinterested champions of human rights. Not at all. The closest any of them have come to admitting any kind of responsibility, let alone regret, is a pseudo mea culpa that occurs towards the end of Lyonel Trouillot's (2012) autobiographical text Objectif: l'autre. It is such a rare bird that it is worth quoting in full. Trouillot says that he has only 'felt bad' twice in his life, and the second occasion was when he heard 'the coordinator of a Haitian "civil society" movement pleading in front of the Parliament against the raising of the minimum wage.' He continues:

A Haitian worker earns less than five euros a day. I had taken risks with that man when the government [of Aristide] was using banditism as a political weapon and was sliding towards totalitarianism in the first half of the 2000s. It looked as if the Haitian bourgeoisie was finally accepting that it was not possible to build a modern society without tackling the glaring inequalities that forbid Haitians access to a common sphere of citizenship. Once the government had been overthrown, that bourgeoisie simply returned to its old habits of exclusion and unregulated exploitation (exploitation sauvage). I reproach myself, I reproach all of those people, people of the left, who had participated in that movement, for not having been more vigilant, for not having forced these champions of exclusion masquerading as democrats to make the effort of humanity that would show that there is more to them than their appetites and their desire to continue enjoying their rents and their privileges untroubled by the slightest pang of guilt (sans état d'âme). (Trouillot, 2012: 208-209)

One is left almost speechless by the bad faith on display in that quotation. Could Trouillot seriously expect his readers to believe that he was disappointed and surprised to see this anonymous businessman (in fact, the sweatshop magnate Andy Apaid Jnr.) oppose the raising of the minimum wage? Had he perhaps been looking the other way when, after Aristide's re-election in 2000, Apaid, along with virtually every businessman in the G184, had opposed Aristide's attempts to raise the minimum wage, as they had the first time he was elected, in 1990? It is no more credible that Trouillot should have been surprised that Haiti's so-called MREs (Morally Repugnant Elites: the clue is in the name) should have reverted to their 'habits of exclusion and unregulated exploitation'. As a connoisseur of Kreyòl proverbs, Trouillot is doubtless familiar with the phrase 'bourik swe pou chwal dekore ak dentèl' (lit: the donkey sweats so that the horse can be adorned with lace). As for Trouillot himself, he emerges with his credentials as 'man of the left' and 'champion of the downtrodden' enhanced by his denunciation of the perfidy of his erstwhile comrade in arms ('I had taken risks with that man').

The fact is that it is not only the Haitian business elites, the State Department and US financial institutions and corporations looking for business opportunities who

(c) 2013 The Authors. Bulletin of Latin American Research published by John Wiley \& Sons Ltd on behalf of the Society for Latin American Studies.

Bulletin of Latin American Research Vol. 32, No. 4 
benefited richly from the ousting of Aristide. Trouillot and his band of merry 'scribes' did quite well too. Above all, they got what the narcissist craves: recognition. Since 2004, Collectif Non! writers have been awarded more than a dozen literary prizes, many of them more or less in the gift of the French government. But the gratitude ('reconnaissance', in French, means both gratitude and recognition) of the Chirac and Sarkozy administrations went further than literary prizes: on 10 January 2010, Raoul Peck-a leading member of the G184 and a film-maker of decidedly modest achievements - was made President of the 'Ecole nationale supérieure des métiers de l'image et du son' (normally known as 'La Fémis', or French National Film School) by presidential decree; Victor and Trouillot are both 'Chevaliers des Arts et des Lettres de la France', but they are trumped by Frankétienne, who was made a 'Commandeur' of that Order in 2010; back in Haiti, Magalie Comeau-Denis was made Minister of Culture and Communication in the de facto regime imposed by the USA after Aristide's removal; Lyonel Trouillot was appointed to a junior position in that ministry; Pierre Buteau was named Minister of National Education, Youth, Sport and Civic Education. Frankétienne, meanwhile, came close to deification when, in 2006, he was proclaimed a 'Living National Treasure' by a foundation created by several Haitian business elites, the 'Fondation Françoise Canez Auguste et Image et Marketing'.

At the start of this section, I referred to Refonder Haiti? as a simulacram. I was alluding to the uncanny quality of much of the writing in that volume: indictments that appear genuinely impassioned, prescriptions that appear rational and well-reasoned, lamentations so heart-rending that one can almost perceive the dried tear-stains on the paper; yet all of that is totally divorced from a context that would allow readers to take full measure of the object they hold in their hands: not one of the sixteen erstwhile G184 members sees fit to remember that glorious past in the 'notes on contributors'. Even the note on Camille Chalmers, which lists at great length his manifold achievements and honours, omits to mention the moment in January 2004 when he threw in his lot with the 'tiny minority' and the 'imperialist powers' (see above): in a press-release for PAPDA, he wrote:

Aristide must go immediately. The Haitian Platform to Advocate for an Alternative Development (PAPDA) praises the courage and foresight of the Haitian people who are mobilising in greater numbers every day to demand the resignation of President Jean-Bertrand Aristide. PAPDA is happy to associate itself with this demand and reiterates its conviction that President Aristide's departure constitutes an essential element of any real way out of the crisis facing the country today. (PAPDA, 2004)

The press release is headed, in large capitals: 'PAPDA is opposed to the intervention of any multinational police or military force on Haitian soil under the pretext of re-establishing order'. He might just as well have handed to the French, Americans and Canadians - whose intentions were by then quite clear (Hallward, 2007: 91) - a handful of bullets, saying 'but if you use them, I take no responsibility for the consequences!' Ultimately, Chalmers' complicity in a situation of oppression that he now decries, seriously weakens the moral force behind his article in Refonder Haïti?.As I move towards a conclusion, I feel that I should address a foreseeable criticism of the foregoing. This article was not conceived as a paean to Aristide or to what was left of Fanmi Lavalas by 2004. I hold no personal brief for Aristide: I tend to think that he was a quite seriously flawed leader. But this is not about the personal qualities of Aristide, nor even about the success or failure of his administrations. It is about a people who 


\section{Writing from and about Haiti after the Earthquake}

twice glimpsed a fleeting chance of empowerment, only to see that chimera evaporate before its eyes. One obstinate fact remains - and it is a fact that sticks in the craw of the unelectable Apaid, and the unrepresentative Trouillot: Aristide was democratically elected by a huge popular majority in 2000; a mature, responsible opposition would have allowed Aristide to see out his mandate and would have put their alternative vision before the people in the next election. As it is, in not only calling for the departure of Aristide but actively working for his removal, they sent the message that democratic elections were fine, but only so long as their result was acceptable to the Haitian elites and the US State Department.

The narcissism of the virtual totality of what passes for an intelligentsia in Haiti is matched only by their irresponsibility: things 'happen' but like Eliot's Macavity, they are never there. What are we to make of 'committed intellectuals' who take responsibility for nothing? But 'we' also need to look in the mirror, even if we may not like what we see there. We have our own narcissism to confront. The veritable Haiti industry that has sprung up (particularly) in North American and French academic circles in recent years received a shot in the arm after January 2010 - not unlike that received by the neo-liberal 'project' for Haiti. Haitian writers are invited to conferences and colloquia in order to be admired, and because it is thought that their presence adds the cachet of 'authenticity' to the proceedings. But never once does anyone dare to ask them who or what they represent. In short, it behoves academics working in the centres of what Trouillot half-ironically calls the 'empire' (Trouillot, 2009: 128) to cease preferring interlocutors from the South on the basis of some supposed resemblance. Let us start questioning the oracular status of these 'good elites' and recognise them for the consummate ventriloquists that they are. Perhaps then we can seek out, listen to, and amplify the voices we have allowed them to silence.

\section{References}

Amnesty International (2004) Haiti: Chamblain and Joanis Overnight Trials are an Insult to Justice. [WWW document]. URL http://www.amnesty.org/en/library/asset/AMR36/005/ 2005/en/64967b18- d4dc-11dd-8a23-d58a49c0d652/amr360052005en.html [accessed 1 May 2012].

Amnesty International (2005) Haiti. Disarmament Delayed, Justice Denied. [WWW document]. URL http://www.amnesty.org/en/library/asset/AMR36/005/2005/en/73b220cbd4dc-11dd-8a23-d58a49c0d652/amr360052005en.pdf [accessed 1 May 2012].

Bongie, C. (2008) Friends and Enemies. The Scribal Politics of Post/Colonial Literature. Liverpool University Press: Liverpool.

Brutus, E. and Chalmers, C. (2010) 'Construire et reconstruire Haïti? Acteurs, enjeux et représentations' in P. Buteau, R. Saint-Éloi and L. Trouillot (eds.) Refonder Haïti. Mémoire d'Encrier: Montreal, 33-45.

Buteau, P., Saint-Éloi, R. and Trouillot, L. (eds.) (2010) Refonder Haïti. Mémoire d'Encrier: Montreal.

Chomsky, N., Farmer, P. and Goodman, A. (2004) Getting Haiti Right This Time The U.S. and the Coup. Common Courage Press: Monroe.

Collectif Non (2004) Jusqu'où ira l'International dans l'acceptation de l'inacceptable? [WWWdocument]. URL http://www.alterpresse.org/spip.php?article1111 [accessed 1 May 2012].

Dubois, L. (2012) Haiti. The Aftershocks of History. New York: Metropolitan Press.

Dupuy, A. (2007) The Prophet and Power. Jean-Bertrand Aristide, the International Community, and Haiti. Rowman and Littlefield: Lanham.

(c) 2013 The Authors. Bulletin of Latin American Research published by John Wiley \& Sons Ltd on behalf of the Society for Latin American Studies.

Bulletin of Latin American Research Vol. 32, No. 4 
Fleurimond, W. K. (2009) Haïti de la crise à l'occupation. Histoire d'un chaos (2000-2004). L'Harmattan: Paris.

Frankétienne, Trouillot, L. and Victor, G. (2004) Ecrire Haïti... Frankétienne, Lyonel Trouillot, Gary Victor... 'perdu dans l'utopie'. [WWW document]. URL http://www. africultures.com/php/index.php?nav=article\&no=3419\&texte_recherche=trouillot franketienne victor [accessed 1 May 2012].

Gautheret, J. (2010) 'Haïti, la malédiction'. Le Monde, 15 January 2010, 2.

Griffin, T. M. (2004) Haiti Human Rights Investigation: November 11-21, 2004. Center for the Study of Human Rights, University of Miami School of Law, Miami.

Hallward, P. (2007) Damming the Flood. Haiti, Aristide and the Politics of Containment. Verso: London.

Ives, K. and Herz, A. (2011) Wikileaks: The Aristide Files. [WWW document]. URL http://www.thenation.com/article/162598/wikileaks-haiti-aristide-files [accessed 1 May 2012].

Laferrière, D. (2010) Tout bouge autour de moi. Grasset: Paris.

Lahens, Y. (2010a) 'Haïti ou la santé du malheur'. Libération, 19 January 2010, III.

Lahens, Y. (2010b) Failles. Sabine Wespieseur: Paris.

Mance, A., Smith, Q. and Yagerman, R. (2006) Haiti Human Rights Investigation, March 11-16, 2006. Centre for the Study of Human Rights, University of Miami School of Law.

Peck, R. (2010) “Dead End” à Port-au-Prince : un cinéaste retourne chez lui. [WWW document]. URL http://www.liberation.fr/monde/0101616238-dead-end-a-port-au-princeun-cineaste-retourne-chez-lui [accessed 1 May 2012].

Platfòm Ayisyen pou Pledwaye pou yon Devlopman Alternatif (2004) PAPDA Demands the Immediate Resignation of Jean-Bertrand Aristide. [WWW document]. URL http:// mailman.lbo-talk.org/2004/2004-March/004977.html [accessed 24 February 2013].

Saint-Éloi, R. (2010) Haïti, Kenbe la!. Michel Lafon: Paris.

Soukar, M. (2010) 'La Diaspora et le développement économique d'Haïti: défis et perspectives' in P. Buteau, R. Saint-Éloi and L. Trouillot (eds.) Refonder Haïti. Mémoire d'Encrier: Montreal, 309-322.

The Huffington Post (2010) Pat Robertson: Haiti "Cursed"by "Pact to the Devil". [WWW document]. URL http://www.huffingtonpost.com/2010/01/13/pat-robertsonhaiti-curse_n_422099.html [accessed 2 May 2012].

Trouillot, L. (2009) 'Hallward, or the Hidden Face of Racism'. Small Axe 30: 127-136.

Trouillot, L. (2012) Objectif: l'autre. André Versailles éditeur: Paris.

Winnicott, D. W. (1971) Playing and Reality. Routledge: London. 